Bangladesh J. Zool. 40(1): 109-119, 2012

\title{
TOXICOLOGICAL PROPERTIES OF ACHRAS ZAPOTA (LINN) PLANT PARTS ON THE PREDATORY FISHES HETEROPNEUSTES FOSSILIS (BLOCH) AND CHANNA PUNCTATUS (BLOCH)
}

\author{
Munira Nasiruddin, Mohammad Ali Azadi and Diana Chakma \\ Department of Zoology, University of Chittagong, Chittagong-4331, Bangladesh
}

\begin{abstract}
Toxicological properties of the indigeneous plant Achras zapota (Linn) (Family: Sapotaceae) (locally known as 'Safeda' in Bangla) were assessed on two predatory fishes, Heteropneustes fossilis (Bloch) and Channa punctatus (Bloch), after $24 \mathrm{~h}$ exposure under normal laboratory conditions $\left(25 \pm 3^{\circ} \mathrm{C}\right)$. Distilled water, $50 \%$ and absolute ethyl alcohol solvent extrarcts of the dry seed, leaf, bark and root of A. zapota were tested upon the fishes. Exposed fishes showed hyperactivity with increased opercular movement and accumulation of mucus on the body surface. Increase in the concentration of the extracts caused an increase in the fish mortality. The $\mathrm{LC}_{50}$ values of the distilled water, $50 \%$ ethyl alcohol and absolute ethyl alcohol extracts of $A$. zapota plant parts for $H$. fossilis were $320.80,222.26$, 98.49 ppms, respectively in seed; 480.91, 279.37, 235.76 ppms, respectively in leaf; 630.86, 151.39, 85.21 ppms, respectively in bark and $218.12,122.89,111.62$ ppms, respectively in root. Whereas, the $\mathrm{LC}_{50}$ values of the corresponding plant parts for C. punctatus were 218.12, 146.84, 88.83 ppms, respectively in seed; $279.35,175.89,125.69$ ppms, respectively in leaf; 132.36, 102.91, 78.11 ppms, respectively in bark and 63.87, 39.46, 33.27 ppms, respectively in root. On the basis of the $\mathrm{LC}_{50}$ values of absolute ethyl alcohol extracts, for $H$. fossilis, the order of toxicity was found to be: bark $>$ seed $>$ root $>$ leaf and for $C$. punctatus it was: root $>$ bark $>$ seed $>$ leaf. Of the two test fishes $H$. fossilis was more tolerant and less sensitive to the effects of the plant part extracts than C. punctatus.

Key words: Toxicological properties, Achras zapota, Heteropneustes fossilis, Channa punctatus, bioassay.
\end{abstract}

\section{INTRODUCTION}

In the development and application of piscicides, it would be useful to make a distinction between the objectives which determine the choice of piscicide and mode of application. Because the chemical piscicides are harmful to the environment, these ultimately pollute it. So, it is essential to search that kind of piscicide which is not hazardous for our environment, but affect only the targeted undesirable species. From this point of view, testing of plant materials for such properties may help in the exploration of new plant species.

Piscicides are used in many parts of the world to stupefy or kill fish. Large numbers of plants have piscicidal properties, some of which have been widely used for pond cleansing-control of predatory fish (Tiwari and Singh 2003). Such piscicidal properties of indigenous plant parts were studied to some extent at home by Chowhury et al. (1981) in Derris elliptica and D. scandens root, Latifa et al. $(1987,1988)$ in Tephrosia purpurea (Pers) root, Ahmed (1992) in Camellia sp. seed, Latifa and Begum (1993) in Euphorbia neriifolia (Linn) stem, Latifa 
et al. (1997) in Azadirachta indica (A. Juss) bark, Nasiruddin et al. (1997) in A. indica (A. Juss) seed kernel and seed kernel oil, Nasiruddin et al. (1998) in Albizzia procera (Benth) seed, Swietenia mahagoni (Jacq) seed kernel, Suregada multiflora (Juss) seed and Sapium indicum (Wild) seed kernel, Latifa et al. (2002) in Diospyros ebenum (Koen) bark, Latifa et al. (2004, 2006) in Leucaena leucocephala (Lim. De wit) bark and seed oil, Latifa and Parvin (2006) in Nerium oleander (Linn.) root and Nasiruddin et al. (2006) in A. indica and Barringtonia accutangula (Gaertn) plant parts and Nasiruddin et al. (2009) in Acacia auriculaeformes and Mesua ferrea plant parts.

Whilst culturing fish, piscicides derived from indigenous plants are employed in ponds for the eradication of predatory fishes. Such poison materials are safe substitutes as these possess the requisite properties of high potency, easy decomposability and unabated supply. The objectives of the present study was to evaluate the toxicological properties of the plant parts of the indigenous plant Achras zapota (Linn) on two predatory fishes, Heteropneustes fossilis (Bloch) and Channa punctatus (Bloch) using a quick-kill method which might be employed by the local fishermen for culturing commercial species.

\section{MATERIAL AND METHODS}

During the experiments, the toxicants were obtained from the dry seed, leaf, bark and root of A. zapota (Linn) commonly known as 'Safeda' locally. The experimental fishes were collected from different fish markets of Chittagong city and acclimatized in the laboratory for 4-5 hours. For the dry seed, leaf, bark and root preparation, fresh parts were collected, cleaned and dried in diffused sunlight. The parts were separately chopped, pulverized in a power driven grinder, sieved and then mixed with required amount of distilled water, $50 \%$ or absolute ethyl alcohol. The mixture was stirred thoroughly in a magnetic stirrer for 4-5 hours for ensuing maximum extraction. The resultant liquid was filtered and the filtrate was used for stocking.

In the present study, $24 \mathrm{~h}$ duration experiments were carried out as short time experiments and the bioassays were conducted to determine the toxicity of the three different solvent extracts. A series of glass aquaria $(30 \times 23 \times 23 \mathrm{~cm})$ each was containing five liters of tap water and toxicant as calculated (APHA 1976) were used. The range of concentrations was selected on the basis of preliminary screening tests to determine $10-90 \%$ mortality. In each test, a set of five fishes were released at random in each concentration which was replicated twice at room temperatures $25 \pm 3^{\circ} \mathrm{C}$. Abnormal behavioural responses, nature of death of the fishes and mucus accumulation on the body after the death of 
the fishes exposed to the absolute ethyl alcohol extracts were recorded. Mortality in all series of experiments was recorded in terms of percentage.

Comparison data of the dose concentrations of the four plant part extracts against the two test fishes was statistically done using students t-test. Mortality data were subjected to probit analysis (Finney 1971). Values of $\mathrm{LC}_{50}$ were determined following a computer based probit analysis programme. The values of Chi-square $\left(\mathrm{x}^{2}\right)$ were determined to see the difference between the expected and observed mortalities at 0.05 level. The analysis of variance of percentage mortality of fishes was made to estimate the variation among the treatments at 0.01 level. The relative potency values amongst the extracts were calculated by taking the highest $\mathrm{LC}_{50}$ value as unit.

\section{RESULTS AND DISCUSSION}

\section{Effects of the extracts on the behaviour of the fish}

Behaviour of the control fishes: $H$. fossilis in the control set were normal in behaviour with gentle body movement. They remained active and vigorous throughout the experiments. All the fishes were morphologically and physically well balanced. Their swimming movement, gulping for air, body colour, eyes, barbels and fins were normal. No mucus secretion and mortality was observed.

The controlled set of $C$. punctatus moved gently with regular movement of their pectoral fins. They did not try to jump out of the aquaria. Scales, fins and body colour were normal. Some settled at the bottom of the aquaria for a while and began to move freely. They were also morphologically and physically well balanced.

Effects of A. zapota plant part solvents on the behaviour of $H$. fossilis: With dry seed solvents, the exposed fishes exhibited violent swimming activities within half an hour of exposure to the toxicant. Gulping activity increased with increased opercular movement. This abnormal behaviour continued for a while. There had been a gradual decrease in the swimming activity with time until the fish appeared calm and then died. The dead fishes were stiff and floated at an angle of 45 or $90^{\circ}$. Mucus secretion was prominent.

On exposure to the dry leaf extracts, the fishes showed irregular movement and repeatedly raised towards the surface for taking air. Finally, failing to keep balance they sank to the bottom of the aquaria. Most of the dead fishes were found to lay at the bottom of the aquaria. Less amount of mucus was seen to accumulate over the body.

The test fishes were highly excited upon exposure to the dry bark extract. They showed immediate reaction by trying to jump out of the aquaria. A few 
swam erratically and others swam towards the surface gulping for air. Gradually they lost their balance, remained stupefied for sometimes and died. Dead fishes with wide mouth openings were seen floating parallel or at an angle of $90^{\circ}$. They were stiff and sticky, being covered with a great deal of mucus.

In the dry root extracts, the fishes showed their abnormality within one hour of exposure to the toxicant. At that time they moved rapidly around the surface and gulped for air. Ultimately they lost their balance and settled to the bottom. The fishes died at different intervals, were found floating or drown at the bottom of the aquaria. Mucus was secreted to some extent.

Effects of A. zapota plant part solvents on the behaviour of C. punctatus: The fishes showed excitability within an hour after exposure to the dry seed extracts. They showed erratic swimming and behavioural abnormality. Gradually they lost equilibrium, settled to the bottom and died at different time intervals. The dead fishes floated at various angles with their ventral side upward. Scales were shed to some extent. Mucus secretion was quite profuse.

In the dry leaf extracts the first visible reaction started after an hour whence they showed abnormal behaviour such as restlessness, prompt opercular activities, strong spasm and finally became imbalanced. At last the affected fishes became paralysed and settled down to the bottom of the aquaria. They gradually died at intervals and were seen to lay at the bottom of the aquaria with their ventral side upwards.

With dry bark extracts, the fishes demonstrated vigorous movement within half an hour and tried to jump out of the aquaria. Most of them swam erratically near the surface and gulped for air. Gradually they lost their balance and settled down. The scales of the dead fishes were seen to be shed. Dead fishes floated near the water surface with their belly directing upward. A great deal of mucus secretion was observed.

The fishes showed abnormal and irregular activities upon exposure to the dry root extracts within 20 minutes. Immediately upon exposure to the toxicant they jumped upward and outward. After a while such behavior ceased, but they were very restless dashing inside the aquaria. Gradually their opercular movement ceased with occasional gulping for air. At the end they lost their stamina, became paralysed and died. Most of the dead fishes were seen floating parallel to the water surface with their ventral side upward. Scales were shed off to a great extent. Profuse yellowish mucus covered the body.

During the experiments the acutely toxicated fishes of both the species exhibited high excitability and various abnormal reactions which included jerky movement, quick surfacing, erratic swimming, gulping for air, loss of balance and paralysis. They often came to the water surface and exhibited gulping 
activity and increased opercular movement indicating respiratory distress. Important local effects on fins, barbels, skin and scales were observed in the dead fishes. The dead fishes floated at various angles which was also remarkable and mucus secretion was evident over the body. More or less similar types of behaviour were observed in fishes treated with various plant extracts (Latifa et al. 1987, 1988, 1992, 1997, 2002, 2004 and Nasiruddin et al. 1997, 1998 and 2006). Regarding the physical responses in fishes after their introduction in the different toxicants Wedemeyer (1970) observed agitated swimming behaviour in Salmo gairdneri and Sharma et al. (1978) also observed the same sort of behaviour in mudskipper (Pseudapocryptes dentatus), Gambusia (Gambusia affinis) and Kill fish (Aphanius mento). Black and Conner (1964) and Wedemeyer (1970) suggested that immediate irritation to the fish upon introduction to the toxicant is due to its effect on the gill membrane whereas Bennet and Dooley (1982) regarded mucus secretion as defensive and excretory response.

\section{Toxicological effects of the plant parts on mortality of the fish}

Effect of the distilled water, 50\% ethyl alcohol and absolute ethyl alcohol solvent extracts of A. zapota on the mortality of $H$. fossilis and C. punctatus is shown in Table 1 . The regression equation, chi-square, $\mathrm{F}$-test, $\mathrm{LC}_{50}$ values with their confidence limits and their relevant statistical parameters of different solvents are shown in Table 2. The relative potency values of the extracts are given in Table 3. All solvent extracts appeared to be more or less toxic against the two fish species. The solubilizing capacity of the solvents were ranked as absolute ethyl alcohol $>50 \%$ ethyl alcohol $>$ distilled water. Effect of the distilled water, 50\% ethyl alcohol and absolute ethyl alcohol solvents of A. zapota on the mortality of $H$. fossilis and $C$. punctatus is shown in Table 1 . The regression equation, chi-square, F-test, $\mathrm{LC}_{50}$ values with their confidence limits and their relevant statistical parameters of different solvents are shown in Table 2. The relative potency values of the extracts are given in Table 3.

In case of $H$. fossilis, among the different solvent extracts of $A$. zapota plant parts, the extracts of dry bark with absolute ethyl alcohol was the most toxic having lowest $\mathrm{LC}_{50}$ value of $85.21 \mathrm{ppm}$ and highest relative potency value of 7.40. Whereas, the distilled water dry bark extract was the least toxic with $\mathrm{LC}_{50}$ of $630.86 \mathrm{ppm}$ and relative potency value of 1.00 . The relative positions of the different plant part solvent extracts on the basis of their $\mathrm{LC}_{50}$ and relative potency values, i.e. toxicities are: Absolute ethyl alcohol extract of dry bark > absolute ethyl alcohol extract of dry seed $>$ absolute ethyl alcohol extract of dry root $>50 \%$ ethyl alcohol extract of dry root $>50 \%$ ethyl alcohol extract of dry bark $>$ distilled water extract of dry root $>50 \%$ ethyl alcohol extract of dry seed $>$ 
Table 1. Mortality of Heteropneustes fossilis and Channa punctatus at different concentrations of distilled water, $50 \%$ ethyl alcohol and absolute ethyl alcohol solvents of dry seed, leaf, bark and root of Achras zapota after 24 hour exposure.

\begin{tabular}{|c|c|c|c|c|c|c|c|}
\hline \multirow[b]{2}{*}{$\begin{array}{l}\text { Plant } \\
\text { parts }\end{array}$} & \multirow{2}{*}{ Solvent } & \multicolumn{3}{|c|}{ Heteropneustes fossilis } & \multicolumn{3}{|c|}{ Channa punctatus } \\
\hline & & $\begin{array}{l}\text { Conc. } \\
\text { (ppm) }\end{array}$ & $\begin{array}{c}\text { Log } \\
\text { Conc. }\end{array}$ & $\begin{array}{c}\text { Mortality } \\
\%\end{array}$ & $\begin{array}{l}\text { Conc. } \\
\text { (ppm) }\end{array}$ & $\begin{array}{c}\text { Log } \\
\text { Conc. }\end{array}$ & $\begin{array}{c}\text { Mortality } \\
\%\end{array}$ \\
\hline \multirow{15}{*}{$\begin{array}{l}\text { Dry } \\
\text { seed }\end{array}$} & \multirow{5}{*}{$\begin{array}{l}\text { Distilled } \\
\text { water }\end{array}$} & 150 & 2.18 & 20 & 100 & 2.00 & 20 \\
\hline & & 200 & 2.30 & 30 & 200 & 2.30 & 40 \\
\hline & & 400 & 2.60 & 50 & 300 & 2.48 & 60 \\
\hline & & 600 & 2.78 & 80 & 400 & 2.60 & 80 \\
\hline & & 800 & 2.90 & 90 & 500 & 2.69 & 90 \\
\hline & \multirow{5}{*}{$\begin{array}{l}50 \% \text { ethyl } \\
\text { alcohol }\end{array}$} & 100 & 2.00 & 20 & 50 & 1.69 & 20 \\
\hline & & 200 & 2.30 & 50 & 100 & 2.00 & 30 \\
\hline & & 300 & 2.48 & 60 & 200 & 2.30 & 50 \\
\hline & & 400 & 2.60 & 70 & 300 & 2.48 & 80 \\
\hline & & 500 & 2.69 & 80 & 400 & 2.60 & 90 \\
\hline & \multirow{5}{*}{$\begin{array}{l}\text { Absolute } \\
\text { ethyl } \\
\text { alcohol }\end{array}$} & 50 & 1.69 & 30 & 25 & 1.39 & 10 \\
\hline & & 100 & 2.00 & 50 & 50 & 1.69 & 40 \\
\hline & & 150 & 2.18 & 60 & 100 & 2.00 & 50 \\
\hline & & 200 & 2.30 & 70 & 200 & 2.30 & 70 \\
\hline & & 300 & 2.48 & 90 & 300 & 2.48 & 90 \\
\hline \multirow{15}{*}{ Dry leaf } & \multirow{5}{*}{$\begin{array}{l}\text { Distilled } \\
\text { water }\end{array}$} & 200 & 2.30 & 20 & 200 & 2.30 & 20 \\
\hline & & 400 & 2.60 & 30 & 250 & 2.39 & 40 \\
\hline & & 600 & 2.78 & 50 & 300 & 2.48 & 50 \\
\hline & & 800 & 2.90 & 80 & 350 & 2.54 & 70 \\
\hline & & 1000 & 3.00 & 90 & 400 & 2.60 & 90 \\
\hline & \multirow{5}{*}{$\begin{array}{l}50 \% \text { ethyl } \\
\text { alcohol }\end{array}$} & 100 & 2.00 & 20 & 100 & 2.00 & 20 \\
\hline & & 250 & 2.39 & 40 & 150 & 2.18 & 30 \\
\hline & & 400 & 2.60 & 60 & 200 & 2.30 & 50 \\
\hline & & 550 & 2.74 & 70 & 250 & 2.39 & 80 \\
\hline & & 700 & 2.85 & 90 & 300 & 2.48 & 90 \\
\hline & \multirow{5}{*}{$\begin{array}{l}\text { Absolute } \\
\text { ethyl } \\
\text { alcohol }\end{array}$} & 50 & 1.69 & 20 & 50 & 1.69 & 20 \\
\hline & & 100 & 2.00 & 30 & 100 & 2.00 & 30 \\
\hline & & 250 & 2.39 & 40 & 150 & 2.18 & 50 \\
\hline & & 400 & 2.60 & 60 & 200 & 2.30 & 70 \\
\hline & & 550 & 2.74 & 80 & 250 & 2.39 & 90 \\
\hline \multirow{15}{*}{$\begin{array}{l}\text { Dry } \\
\text { bark }\end{array}$} & \multirow{5}{*}{$\begin{array}{l}\text { Distilled } \\
\text { water }\end{array}$} & 350 & 2.54 & 20 & 80 & 1.90 & 20 \\
\hline & & 550 & 2.74 & 40 & 100 & 2.00 & 40 \\
\hline & & 700 & 2.85 & 50 & 150 & 2.18 & 50 \\
\hline & & 850 & 2.93 & 60 & 200 & 2.30 & 70 \\
\hline & & 1000 & 3.00 & 90 & 250 & 2.39 & 90 \\
\hline & \multirow{5}{*}{$\begin{array}{l}50 \% \text { ethyl } \\
\text { alcohol }\end{array}$} & 50 & 1.69 & 20 & 60 & 1.78 & 20 \\
\hline & & 100 & 2.00 & 40 & 80 & 1.90 & 30 \\
\hline & & 250 & 2.39 & 60 & 100 & 2.00 & 50 \\
\hline & & 350 & 2.54 & 70 & 150 & 2.18 & 70 \\
\hline & & 550 & 2.74 & 90 & 200 & 2.30 & 90 \\
\hline & \multirow{5}{*}{$\begin{array}{l}\text { Absolute } \\
\text { ethyl } \\
\text { alcohol }\end{array}$} & 25 & 1.39 & 20 & 40 & 1.60 & 10 \\
\hline & & 50 & 1.69 & 40 & 60 & 1.78 & 30 \\
\hline & & 100 & 2.00 & 50 & 80 & 1.90 & 50 \\
\hline & & 250 & 2.39 & 70 & 100 & 2.00 & 70 \\
\hline & & 350 & 2.54 & 90 & 150 & 2.18 & 90 \\
\hline
\end{tabular}


Table 1. contd.

\begin{tabular}{|c|c|c|c|c|c|c|c|}
\hline \multirow{15}{*}{ Dry root } & \multirow{4}{*}{$\begin{array}{l}\text { Distilled } \\
\text { water }\end{array}$} & 100 & 2.00 & 20 & 40 & 1.60 & 20 \\
\hline & & 200 & 2.30 & 40 & 60 & 1.78 & 40 \\
\hline & & 300 & 2.48 & 60 & 80 & 1.90 & 70 \\
\hline & & 400 & 2.60 & 80 & 100 & 2.00 & 80 \\
\hline & \multirow{6}{*}{$\begin{array}{l}50 \% \text { ethyl } \\
\text { alcohol }\end{array}$} & 500 & 2.69 & 90 & 120 & 2.08 & 90 \\
\hline & & 50 & 1.69 & 30 & 20 & 1.30 & 20 \\
\hline & & 100 & 2.00 & 40 & 40 & 1.60 & 50 \\
\hline & & 200 & 2.30 & 50 & 60 & 1.78 & 70 \\
\hline & & 300 & 2.48 & 80 & 80 & 1.90 & 80 \\
\hline & & 400 & 2.60 & 90 & 100 & 2.00 & 90 \\
\hline & \multirow{5}{*}{$\begin{array}{l}\text { Absolute } \\
\text { ethyl } \\
\text { alcohol }\end{array}$} & 25 & 1.39 & 10 & 10 & 1.00 & 20 \\
\hline & & 50 & 1.69 & 20 & 20 & 1.30 & 40 \\
\hline & & 100 & 2.00 & 50 & 40 & 1.60 & 50 \\
\hline & & 200 & 2.30 & 70 & 60 & 1.78 & 60 \\
\hline & & 300 & 2.48 & 80 & 80 & 1.90 & 80 \\
\hline
\end{tabular}

absolute ethyl alcohol extract of dry leaf $>50 \%$ ethyl alcohol extract of dry leaf $>$ distilled water extract of dry seed $>$ distilled water extract of dry leaf $>$ distilled water extract of dry bark.

In case of C. punctatus, absolute ethyl alcohol solvent extracts of A. zapota dry root was the most toxic having the lowest $\mathrm{LC}_{50}$ value of $33.27 \mathrm{ppm}$ and highest relative potency value of 8.40 . The least toxic was the distilled water extract of dry leaf with $\mathrm{LC}_{50}$ of $279.35 \mathrm{ppm}$ and relative potency value of 1.00. The relative positions of the solvent extracts on the basis of their $\mathrm{LC}_{50}$ and relative potency values were: Absolute ethyl alcohol extract of dry root $>50 \%$ ethyl alcohol extract of dry root $>$ distilled water extract of dry root $>$ absolute ethyl alcohol extract of dry bark > absolute ethyl alcohol extract of dry seed > $50 \%$ ethyl alcohol extract of dry bark $>$ absolute ethyl alcohol extract of dry leaf $>$ distilled water extract of dry bark $>50 \%$ ethyl alcohol extract of dry seed > $50 \%$ ethyl alcohol extract of dry leaf $>$ distilled water extract of dry seed $>$ distilled water extract of dry leaf.

In case of $H$. fossilis, on the basis of $\mathrm{LC}_{50}$ values the toxicity of A. zapota solvent extracts were found to be ranked in the order: dry bark $>$ seed $>$ root $>$ leaf for absolute ethyl alcohol extracts; dry root $>$ bark $>$ seed $>$ leaf for $50 \%$ ethyl alcohol extracts; and dry root $>$ seed $>$ leaf $>$ bark for distilled water extracts. In case of $C$. punctatus, the order of toxicity was found to be in the order: dry root $>$ bark $>$ seed $>$ leaf for all the three solvent extracts. The order of solubility of the four plant parts in the three solvents was: absolute ethyl alcohol $>50 \%$ ethyl alcohol > distilled water. Similar solubility pattern was observed by Latifa et al. (1987, 1988, 1992, 1997, 2002), Latifa and Begum (1993) and Nasiruddin et al. (2006). Mortality rate of the fishes varied due to the toxic 


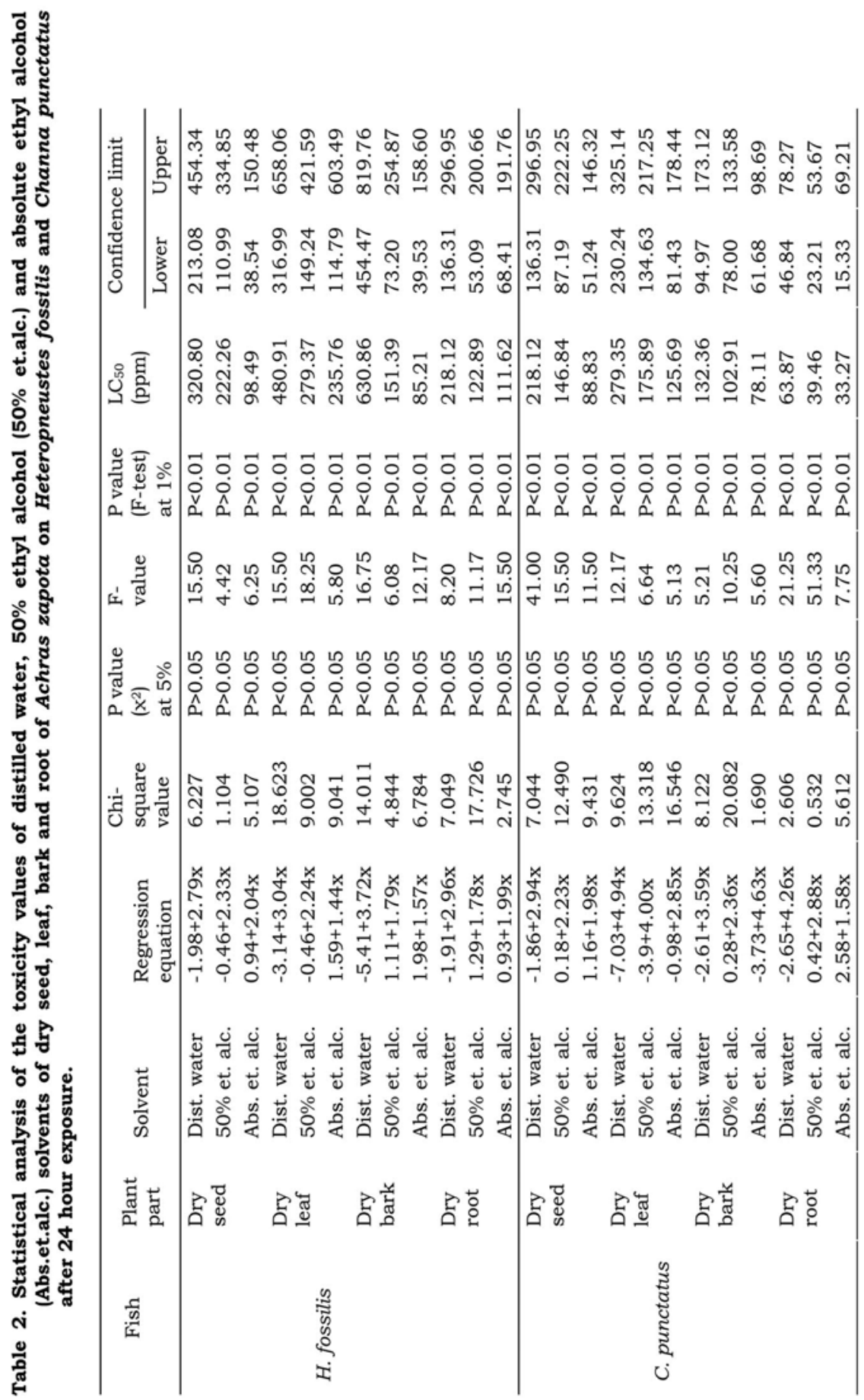


effects of the different solvent extracts, concentrations and also on the species. The difference in sensitivity between closely related species of fishes also emerges from the studies of Mathur (1974) who reported that interspecific variations on the fishes treated with Sevin caused more pronounced physiological reactions in Esomus danrica and Rasbora danoconius. Konar (1977) also reported that the toxicity of Nicotine varied with species. Therefore, it was observed that different concentrations of a solvent extractcaused varying percentages of mortality in the two species of fishes.

Table 3. The $\mathrm{LC}_{50}$ and relative potency values of distilled water, $50 \%$ ethyl alcohol and absolute ethyl alcohol solvents of dry seed, leaf, bark and root of Achras zapota on Heteropneustes fossilis and Channa punctatus after 24 hour exposure.

\begin{tabular}{|c|c|c|c|c|}
\hline Fish & Plant part & Solvent & $\mathrm{LC}_{50}(\mathrm{ppm})$ & $\begin{array}{l}\text { Relative } \\
\text { potency }\end{array}$ \\
\hline \multirow[t]{12}{*}{ H. fossilis } & \multirow[t]{3}{*}{ Dry seed } & Distilled water & 320.80 & 1.966 \\
\hline & & $50 \%$ ethyl alcohol & 222.26 & 2.838 \\
\hline & & Absolute ethyl alcohol & 98.49 & 6.405 \\
\hline & \multirow[t]{3}{*}{ Dry leaf } & Distilled water & 480.91 & 1.312 \\
\hline & & $50 \%$ ethyl alcohol & 279.37 & 2.258 \\
\hline & & Absolute ethyl alcohol & 235.76 & 2.676 \\
\hline & \multirow[t]{3}{*}{ Dry bark } & Distilled water & 630.86 & 1.000 \\
\hline & & $50 \%$ ethyl alcohol & 151.39 & 4.167 \\
\hline & & Absolute ethyl alcohol & 85.21 & 7.403 \\
\hline & \multirow[t]{3}{*}{ Dry root } & Distilled water & 218.12 & 2.892 \\
\hline & & $50 \%$ ethyl alcohol & 122.89 & 5.133 \\
\hline & & Absolute ethyl alcohol & 111.62 & 5.652 \\
\hline \multirow[t]{12}{*}{ C. punctatus } & \multirow[t]{3}{*}{ Dry seed } & Distilled water & 218.12 & 1.281 \\
\hline & & $50 \%$ ethyl alcohol & 146.84 & 1.902 \\
\hline & & Absolute ethyl alcohol & 88.83 & 3.145 \\
\hline & \multirow[t]{3}{*}{ Dry leaf } & Distilled water & 279.35 & 1.000 \\
\hline & & $50 \%$ ethyl alcohol & 175.89 & 1.588 \\
\hline & & Absolute ethyl alcohol & 125.69 & 2.222 \\
\hline & \multirow[t]{3}{*}{ Dry bark } & Distilled water & 132.36 & 2.111 \\
\hline & & $50 \%$ ethyl alcohol & 102.91 & 2.714 \\
\hline & & Absolute ethyl alcohol & 78.11 & 3.577 \\
\hline & \multirow[t]{3}{*}{ Dry root } & Distilled water & 63.87 & 4.374 \\
\hline & & $50 \%$ ethyl alcohol & 39.46 & 7.080 \\
\hline & & Absolute ethyl alcohol & 33.27 & 8.400 \\
\hline
\end{tabular}

Comparing the effects of the extracts of $A$. zapota seed, leaf, bark and root on $H$. fossilis and $C$. punctatus significant difference existed between the doses of distilled water extracts of dry bark and root $(\mathrm{P}<0.05)$. From the $\mathrm{LC}_{50}$ values it is evident that the action of the plant parts was slightly greater on $H$. fossilis than C. punctatus. H. fossilis is more tolerant and less sensitive to the effects of the plant part extracts than C. punctatus. The susceptibility pattern is C. punctatus 
$>$ H. fossilis. Similar type of susceptibility was observed by Biswas (1982) and Nasiruddin et al. $(1997,1998)$, but reverse susceptibility was noticed by Latifa et al. (1987, 1988) and Latifa and Begum (1993). The differential toxicities indicated that probably the physiology (vigour) of the test fishes played an important role in their response to the toxicants (Macek and Mc Allister 1970).

Concluding remarks: In the present study the potentiality of A. zapota plant parts in different dose levels as controlling agents against two predatory and undesirable fish species in the nursery, rearing and stocking ponds has been investigated. The study indicated that the plant parts have piscicidal value which might be helpful to promote culturing of the commercially valuable fish species.

\section{LITERATURE CITED}

AHMED, S.U. 1992. Investigation on the piscicidal property of tea seed (Camelia sp.). Bangladesh $J$. Zool. 20(1): 185-188.

APHA. 1976. Standard methods for the examination of water and waste water. 14th ed. American Public Health Association Press, Washington D.C. 1193 pp.

BENNET, R.O. and DOOLEY, J.K. 1982. Copper intake by two sympatric species of Fundulus heteroclitus and F. majalis (Walbann). J. Fish. Biol. 21: 381-398.

BISWAS, R. 1982. Study of the piscicidal property of the indigenous Derris scandens (Fam. Papilionaceae). M.Sc. thesis, Department of Zoology, University of Dhaka. 119 pp.

BLACK, E.F. and CONNER, A.R. 1964. Effects of MS-222 on glycogen and lactate levels in rainbow trout (Salmo gairdneri). J. Fish. Res. Bd. Can. 21: 1539- 1542.

CHOWDHURY, A.K.A., LATIFA, G.A., ARA, S. and AHMED, R. 1981. Potentiality of indigenous Derris root in cleaning predatory and weed fishes from nursery ponds. Dacca Univ. Stud. B. 29: 47-53.

FINNEY, D.J. 1971. Probit analysis. 3rd ed. Cambridge University Press. London. 333 pp.

KONAR, S. K. 1977. Toxicity of nicotine to aquatic life. Indian J. Fish. 24(1\&2): 124-128.

LATIFA, G.A. and BEGUM, A. 1993. Piscicidal activity of the dry stem of Euphorbia neriifolia (Linn 1753) on Heteropneustes fossilis (Bloch) and Channa punctatus (Bloch). Bangladesh J. Sci. Res. 11(2): 217-225.

LATIFA, G.A. and PARVIN, S.I. 2006. Piscicidal activity of the dry roots of Nerium oleander (Linn.) on Heteropneustes fossilis (Bloch). Bangladesh J. Zool. 34(1): 159-162.

LATIFA, G.A., SHAFI, M., PARVIN, S.I. and CHOWDHURY, A.K.A. 1987. Study on the piscicidal property of the fresh roots of Tephrosia purpurea on fishes Heteropneustes fossilis and Channa punctatus. Dhaka Univ. Stud. Part E 2(1): 13-21.

LATIFA, G.A., SHAFI, M., PARVIN, S.I., ALAM, M.J. and AHMED, M. 1988. Piscicidal property of the dry roots of Tephrosia purpurea (Pers) on Heteropneustes fossilis (Bloch) and Channa punctatus (Bloch). J. Asiat. Soc. Bangladesh Sci. 14(1): 49-55.

LATIFA, G.A., AHSAN, M.F. and SARKER, S.D. 1992. Piscicidal property of the fresh seeds of Mesua ferrea Linn. on Heteropneustes fossilis (Bloch). J. Asiat. Soc. Bangledesh Sci. 18(1): 73-77. 
LATIFA, G.A., BEGUM, S., AKHTER, A. and AHMED, M.S. 1997. Piscicidal properties of the dry barks of Azadirachta indica (A. Juss) on Heteropneustes fossilis (Bloch). Bangladesh J. life Sci. 9(2): 31-36.

LATIFA, G.A., HAMID, A. and SHARMA, G. 2002. Study of piscicidal activity of dry bark of Diospyros ebenum (Koen) on Heteropneustes fossilis (Bloch) and Anabas testudineus (Bloch). Bangladesh J. Life Sci. 14(1\&2): 107-118.

LATIFA, G.A., BACHAR, S.C. and BEGUM, T. 2004. Piscicidal activity of the dry barks of Leucaena leucocephala (Lam. De Wit) on Channa punctatus (Bloch) and Channa striatus (Bloch). Bangladesh J. Zool. 32(2): 247-251.

LATIFA, G.A., BACHAR, S.C., BEGUM, T. and BEGUM, D. 2006. Some effects of Leucaenaleucocephala (Lam. De Wit.) seed oil on Channa punctatus (Bloch). Bangladesh J. Zool. 34(1): 155-158.

MACEK, K.J. and McALLISTER, W.A. 1970. Insecticide susceptibility of some common fish family representatives. Trans. Amer. Fish. Soc. 99: 20-27.

MATHUR, D.S. 1974. Toxicity of Sevin to certain fishes. J. Inland Fish. Soc. India 6: 76.

NASIRUDDIN, M., AZADI, M.A., CHOWDHURY, R. and MAJUMDER, S.M.M.H. 1997. Piscicidal effect of seed kernel extracts and oil of seed kernels of Azadirachta indica A. Juss on two preadatory fishes Heteropneustes fossilis (Bloch) and Anabas testudineus (Bloch). Chittagong Univ. Stud. Part II Sc. 21(1): 53-62.

NASIRUDDIN, M., AZADI, M.A. and CHOWDHURY, R. 1998. Piscicidal effects of seed and seed kernel extracts of four indigenous plants on Heteropneustes fossilis (Bloch) and Anabas testudineus (Bloch). Chittagong Univ. J. Sci. 22(2): 1-10.

NASIRUDDIN, M., AZADI, M.A., CHOWDHURY, R. and SULTANA, M.N. 2006. Studies on the piscicidal properties of Azadirachta indica (A. Juss) and Barringtonia acutangula(Gaertn) plant parts on Heteropneustes fossilis (Bloch). Bangladesh J. Zool. 34(1): 95-104.

NASIRUDDIN, M., AZADI, M.A., and RAHMAN, I.A.S. 2009. Toxicological effect of Accacia auriculaeformes (A. Cuss. Ex Benth.) and Mesua Ferrea (Linn.) plant parts on Heteropneustes fossilis (Bloch). Bangladesh J. Zool. 37(1): 103-112.

SHARMA, K.P., Al-NASIRI, S.K. and BHATTI, M.N. 1978.Toxicity and efficacy of MS-222 on three fishes of Iraq. Bangladesh J. Zool. 6(2): 107-112.

TIWARI, S. and SINGH, A. 2003. Control of freshwater predatory fish, Channa punctatus, through Nerium indicum leaf extracts. Chemosph. 53: 865-875.

WEDEMEYER, G. 1970. Stress of anaesthesia with MS-222 and Benzocaine in rainbow trout (Salmo gairdneri). J. Fish. Res. Bd. Can. 27: 909-914. 